\title{
STATUS REPORT ON STABILITY OF K-RICH PHASES AT UPPER-MANTLE CONDITIONS
}

\author{
George E. Harlow and Rondi Davies \\ American Museum of Natural History, USA
}

\section{INTRODUCTION}

Experimental research on K-rich phases and observations from diamond inclusions, UHP metamorphic rocks, and xenoliths and enclaves from extrusives provide an expanding understanding of the hosts for potassium (and water and fluorine) at mantle conditions. An update is presented:

\section{K-RICH PHASES}

\section{SANIDINE}

In a "dry" environment this feldspar is stable to $6.5 \mathrm{GPa}$ at $1000{ }^{\circ} \mathrm{C}$ (see Table 1), breaking down to $\mathrm{K}_{2} \mathrm{Si}_{4} \mathrm{O}_{9}+$ $\mathrm{Al}_{2} \mathrm{SiO}_{5}+\mathrm{SiO}_{2}$, and has been found as inclusions in diamonds and kyanite eclogites (always in eclogite association). Abundant fluid inclusions or strong $\mathrm{H}_{2} \mathrm{O}$ signature in IR, in certain cases, makes K-cymrite a logical precursor (see below).

\section{K-RICH CLINOPYROXENE}

K-rich clinopyroxene $\left(\mathrm{Kcpx}-\mathrm{KM}^{3+} \mathrm{Si}_{2} \mathrm{O}_{6}\right)$ : Experiments show that Kcpx can become an important component in clinopyroxenes at pressures above 4-5 GPa, depending upon coexisting K-bearing phases (or the lack thereof) but not, apparently, upon temperature (Luth, 1997; Harlow, 1997; Perchuk, 2002). Maximum Kcpx content can reach $\sim 25 \mathrm{~mol} \%$ with $17 \mathrm{~mol} \%$ the highest reported from a natural (UHP) sample (see Perchuk, 2002), other K-rich clinopyroxene (cpx) being found as inclusions in diamonds (e.g., Harlow and Veblen, 1991; see Perchuk, 2002). The partition coefficient for calcic cpx and melt, ${ }^{\mathrm{K}} \mathrm{D}_{\text {cpx/liquid, }}$, above $7 \mathrm{GPa} \cong 0.1-0.2$ and requires ultrapotassic liquids (inferred to require carbonatitic melt or a fluid rather than a silicate melt; e.g., Konzett and Fei, 2000; Perchuk et al., 2002) to form highly potassic cpx or requires a "critical" cpx solid-solution reaction with a liquid (Safonov, personal communication). Chamoro et al. (2002) have confirmed ${ }^{\mathrm{K}} \mathrm{D}_{\text {cpx/liquid }}$ values $\geq 0.2$ for diopsidic cpx $\left(\mathrm{Di}-\mathrm{Jd}_{\mathrm{ss}}\right)$ and lower values, $\sim 10^{-2}$, for jadeitic cpx. As cpx can be a liquidus-to-subsolidus product, the only critical requirements in the formation of $\mathrm{K}$-rich cpx is calcic cpx stability and $\mathrm{K}$ content in the phase assemblage, however, coexisting K-rich solids (e.g., sanidine, K-rich amphibole) reduce the K-content of the cpx coexisting with a melt relative to that in a cpxmelt pair where no K-rich solids are present (e.g., Konzett and Fei, 2000; Mitchell, 1995). Some, thus, interpret high Kcpx contents $\left(>1 \mathrm{wt} \% \mathrm{~K}_{2} \mathrm{O}\right)$ to be the result of cpx growth in the absence of another coexisting K-rich phase (or growth from a K-rich fluid/melt) followed by encapsulation-preservation to avoid reequilibration/unmixing that would reduce the Kcpx content. A review of experimental results is provided by Perchuk et al. (2002). Oxidized iron-rich assemblages (e.g., some lamproites/lamprophyres/etc. - Mitchell, 1995; Mellini and Cundari, 1989) may enable a ferric Kcpx at somewhat lower pressures than $5 \mathrm{GPa}$ and is being investigated.

\section{Phlogopite}

In peridotites, phlogopite is stable to $>6 \mathrm{GPa}$ at $1100{ }^{\circ} \mathrm{C}$ and to between 8 and $12 \mathrm{GPa}$ at $1250-1350{ }^{\circ} \mathrm{C}$ in diopside (Di) plus phlogopite (Phl) assemblages (depending on bulk composition, see Harlow 2002) above which $\mathrm{P}$ and $\mathrm{T}$ either amphibole or liquid is more stable. When fluorine is present, it generally increases in $\mathrm{Phl}$ upon increasing $\mathrm{P}$ (and probably $\mathrm{T}$ ) to about $6 \mathrm{GPa}$, but reactions to form amphibole and/or $\mathrm{KMgF}_{3}$ limit $\mathrm{F}$ content between 6 and $8 \mathrm{GPa}$ (Harlow, 2002). In peralkaline KNCMASH, Phl persists to $10 \mathrm{GPa}$ at $\sim 1300$ ${ }^{\circ} \mathrm{C}$ (see Konzett and Fei, 2002). In more pelitic compositions, $\mathrm{Phl}$ breaks down at low P and T $(\sim 3 \mathrm{GPa}$ at $1000{ }^{\circ} \mathrm{C}$ ) to phengite \pm sanidine \pm fluid (see Massone, 1999).

\section{Phengitic muscovite}

Phengite stability has been examined in "wet" graywacke and K-rich basalt compositions (Schmidt, 1996), a bulk composition approximating something between mica and a pelitic sediment (Domanik and Holloway, 1996), and calcareous metapelite (Domanik and Holloway, 2000) over the general range of $7-11 \mathrm{GPa}$ and 750 to $1100{ }^{\circ} \mathrm{C}$ (see Table 1). Upon increasing pressure phengite yields to K-hollandite stability between 8 and $11 \mathrm{GPa}$ and 750 $900{ }^{\circ} \mathrm{C}$, the transition pressure perhaps depending on bulk composition, such as alumina content. Melt breakdown of the mica occurs above $900{ }^{\circ} \mathrm{C}$ at low bulk $\mathrm{Al}$ content and above $1075-1150{ }^{\circ} \mathrm{C}$ at $7-8 \mathrm{GPa}$ and high $\mathrm{Al}$ content. 


\section{Table 1: Potential K-rich Mantle Minerals}

\begin{tabular}{|c|c|c|c|}
\hline Mineral & Composition & Stability & Citations \\
\hline Sanidine & $\mathrm{KAISi}_{3} \mathrm{O}_{8}$ & to $\sim 6 \mathrm{GPa}, 1200^{\circ} \mathrm{C}$ & $\begin{array}{l}\text { Yagi et al. (1994), Urakawa et } \\
\text { al. (1994) }\end{array}$ \\
\hline $\begin{array}{l}\text { Phengitic } \\
\text { muscovite }\end{array}$ & $\mathrm{KAl}_{2-x} \mathrm{Mg}_{\mathrm{x}} \mathrm{Al}_{1-\mathrm{x}} \mathrm{Si}_{3+\mathrm{x}} \mathrm{O}_{10}(\mathrm{O}$ & $\begin{array}{l}\text { I }_{2} \\
\text { to } 9.5-10,750-1050{ }^{\circ} \mathrm{C} \\
\text { to } 8-11 \mathrm{GPa}, 750-1050{ }^{\circ} \mathrm{C}\end{array}$ & $\begin{array}{l}\text { Schmidt (1996) } \\
\text { Domanik and Holloway (2000) }\end{array}$ \\
\hline Phlogopite & $\begin{array}{l}\mathrm{KMg}_{3} \mathrm{AlSi}_{3} \mathrm{O}_{10}(\mathrm{OH})_{2} \\
\mathrm{KMg}_{3} \mathrm{AlSi}_{3} \mathrm{O} 10(\mathrm{~F})_{2}\end{array}$ & $\begin{array}{l}\text { to } \sim 9 \mathrm{GPa}, 1400^{\circ} \mathrm{C} \\
\text { to } \sim 10 \mathrm{GPa}, 1400^{\circ} \mathrm{C}\end{array}$ & $\begin{array}{l}\text { Luth (1997) } \\
\text { Harlow (2002) }\end{array}$ \\
\hline KK-richterite & $\mathrm{K}(\mathrm{Ca}, \mathrm{K}, \mathrm{Na})_{2} \mathrm{Mg}_{5}(\mathrm{Si}, \mathrm{Al})_{8}$ & $\begin{array}{l}\text { from } 7 \mathrm{GPa} @ 1000{ }^{\circ} \mathrm{C} \\
\text { to }>15 \mathrm{GPa} @ 1400{ }^{\circ} \mathrm{C} \\
\text { from } 8 \mathrm{GPa} @ 1100^{\circ} \mathrm{C} \\
\text { to } 14 \mathrm{GPa} @ 1400{ }^{\circ} \mathrm{C} \\
2(\mathrm{~F}, \mathrm{OH})_{2} \\
\text { to } 13 \mathrm{GPa} @ 1400^{\circ} \mathrm{C}\end{array}$ & $\begin{array}{l}\text { Luth (1997), Sudo \& } \\
\text { Tatsumi (1991), } \\
\text { Harlow (2002) } \\
\text { Konzett \& Fei (2000) } \\
\text { Konzett \& Ulmer (1999) } \\
\text { Konzett \& Fei (2000) }\end{array}$ \\
\hline (21)-MHP & \multicolumn{2}{|c|}{$\mathrm{KNa}_{2} \mathrm{Ca}_{2} \mathrm{Mg}_{6} \mathrm{AlSi}_{12} \mathrm{O}_{34}(\mathrm{OH})_{2}$} & $\begin{array}{l}\text { Konzett \& Fei (2000) } \\
\text { Konzett \& Japel (in press) }\end{array}$ \\
\hline K-clinopyroxene & $\mathrm{K}(\mathrm{Al}, \mathrm{Cr}) \mathrm{Si}_{2} \mathrm{O}_{6}-\mathrm{Cpx}_{\mathrm{ss}}$ & $\begin{array}{l}5 \text { to } 15 \mathrm{GPa}, 1000-1500{ }^{\circ} \mathrm{C} \\
\text { Kcpx1 to Kcpx } 20\end{array}$ & $\begin{array}{l}\text { Harlow (1997), Wang \& } \\
\text { Takahashi (1999) }\end{array}$ \\
\hline $\begin{array}{l}\text { Si-wadeite } \\
\text { (or K-wadeite) }\end{array}$ & $\mathrm{K}_{2} \mathrm{Si}_{4} \mathrm{O}_{9}$ & $\begin{array}{l}\text { from } 6 \mathrm{GPa} @ 1000{ }^{\circ} \mathrm{C} \\
\text { to } \sim 12 \mathrm{GPa} @ 1500{ }^{\circ} \mathrm{C}\end{array}$ & $\begin{array}{l}\text { Yagi et al. (1994), } \\
\text { Harlow (1997) }\end{array}$ \\
\hline $\begin{array}{l}\text { K-cymrite } \\
\text { (or sanidine hydrate }\end{array}$ & $\begin{array}{l}\mathrm{KAISi}_{3} \mathrm{O}_{8} \cdot \mathrm{nH}_{2} \mathrm{O}(\mathrm{n} \leq 1) \\
\text { te) }\end{array}$ & $\begin{array}{l}\text { from } 2.5 \mathrm{GPa} @ 400{ }^{\circ} \mathrm{C} \\
\text { to } 8 \mathrm{GPa} @ 1200{ }^{\circ} \mathrm{C}\end{array}$ & $\begin{array}{l}\text { Fasshauer et al. (1997), } \\
\text { Thompson et al. (1998) } \\
\text { This work }\end{array}$ \\
\hline $\mathrm{KMgF}_{3}$-perovskite & $\mathrm{KMgF}_{3}$ & to $\geq 8 \mathrm{GPa} @ 1400{ }^{\circ} \mathrm{C}$ & Harlow (2002) \\
\hline Al-rich phase & {$[\mathrm{K}, \mathrm{Na}]_{0.9}[\mathrm{Mg}, \mathrm{Fe}]_{2}[\mathrm{Mg}, \mathrm{Fe}$} & $\begin{array}{l}\mathrm{I}, \mathrm{Si}]_{6} \mathrm{O}_{12} \\
\geq 24 \mathrm{GPa} @ 1700-1800{ }^{\circ} \mathrm{C}\end{array}$ & Gasparik \& Litvin (2002) \\
\hline K-phase 1 & $(\mathrm{~K}, \mathrm{Na})_{2} \mathrm{Mg}_{4} \mathrm{Si}_{4} \mathrm{O}_{13}$ & $\begin{array}{l}16 ? \mathrm{GPa} @ 1600{ }^{\circ} \mathrm{C} ? \\
\text { to } 20 \mathrm{GPa} @<<1900^{\circ} \mathrm{C}\end{array}$ & $\begin{array}{l}\text { Wang \& Takahashi (2000), } \\
\text { Gasparik \& Litvin (2002) }\end{array}$ \\
\hline K-hollandite & $\mathrm{KAISi}_{3} \mathrm{O}_{8}$ & $\begin{array}{l}\text { from } \sim 9 \mathrm{GPa} @>1000^{\circ} \mathrm{C} \\
\text { to }>25 \mathrm{GPa} @>1600{ }^{\circ} \mathrm{C}\end{array}$ & $\begin{array}{l}\text { Yagi et al. (1994), Urakawa et } \\
\text { al. (1994), Wang \& Takahashi } \\
\text { (1999) }\end{array}$ \\
\hline K-Ti silicates & $\begin{array}{l}\mathrm{K}_{4} \mathrm{Ti}_{2} \mathrm{Si}_{7} \mathrm{O}_{20} \text { to } \\
\mathrm{K}_{4} \mathrm{TiSi}_{8} \mathrm{O}_{20}\end{array}$ & from 6 GPa @ 1100-1400 C & Mitchell (1995) \\
\hline
\end{tabular}

\section{AMPHIBOLE - ${ }^{M 4}$ K-SUBSTITUTED POTASSIC RICHTERITE}

This amphibole, sometimes called K-richterite or KKrichterite (ideally $\mathrm{K}[\mathrm{KCa}] \mathrm{Mg}_{5} \mathrm{Si}_{8} \mathrm{O}_{22}[\mathrm{OH}, \mathrm{F}]_{2}$ ), has been produced from $\mathrm{Di}+\mathrm{Phl}$ and K-rich peridotitic compositions at $\mathrm{P}>7$ to $15 \mathrm{GPa}$ (see Table 1), above which it breaks down to phase $\mathrm{X}$ and/or liquid. Various experimental studies have shown that $\mathrm{K}$ content is positively correlated with $\mathrm{P} ; \mathrm{Al}$ and $\mathrm{F}$ content decrease with $\mathrm{P}$; and $\mathrm{F}$ content is positively correlated with $\mathrm{T}$ but lowered by coexisting $\mathrm{KMgF}_{3}$ (Harlow, 2002). In less $\mathrm{K}-$ rich bulk compositions, such as natural KLB-1, amphibole breaks down at $12-13 \mathrm{GPa}$ and $1200{ }^{\circ} \mathrm{C}$ (see Konzett and Fei, 2002). Amphibole is a major potential 
reservoir in the upper mantle at depths exceeding $\sim 200$ $\mathrm{km}$.

\section{PHASEX}

Phase $\mathrm{X}$, a potassium di-magnesium acid disilicate $\left(\left[\mathrm{K}_{1-\mathrm{x}-\mathrm{n}}\right]_{2}\left[\mathrm{Mg}_{1-\mathrm{n}} \mathrm{M}^{3+}{ }_{\mathrm{n}}\right]_{2} \mathrm{Si}_{2} \mathrm{O}_{7} \mathrm{H}_{2 \mathrm{x}}\right)$, was discovered in synthesis products in various studies at $\mathrm{T}=1150-1400{ }^{\circ} \mathrm{C}$ and $\mathrm{P}=$ 9-17 GPa (e.g., Luth, 1997; Harlow, 1997; Konzett and Ulmer, 1999). Its maximum stability in KNCMASH and KLB-1 peridotite reaches 20-23 GPa at $1500-1700{ }^{\circ} \mathrm{C}$ where it breaks down to K-hollandite; the stability limit is reduced by a few GPa in subalkaline KNCMASH (Konzett and Fei, 2000). Thus, phase $\mathrm{X}$ is a potential host for $\mathrm{K}$ and $\mathrm{H}_{2} \mathrm{O}$ in the mantle to the bottom of the transition zone. The composition of phase- $\mathrm{X}$ is not fixed but actually represents a solid solution in the stoichiometries $\quad{ }_{2} \mathrm{Mg}_{2} \mathrm{Si}_{2} \mathrm{O}_{7}-\left(\mathrm{K} \quad \mathrm{Mg}_{2} \mathrm{Si}_{2} \mathrm{O}_{7} \mathrm{H}-\right.$ $\mathrm{K}_{2} \mathrm{Mg}_{2} \mathrm{Si}_{2} \mathrm{O}_{7} \mathrm{H}_{2}$, where the center part of the solid solution series appears to be the most stable portion at the conditions examined so far.

\section{K-HOLLANDITE}

$\mathrm{KAlSi}_{3} \mathrm{O}_{8}$, in which $\mathrm{Al}$ and $\mathrm{Si}$ are both 6-coordinated, is stable from $\sim 9 \mathrm{GPa}$ through condition of the lower mantle and appears to be the main K-rich solid-phase reservoir for potassium through the transition zone to the lower mantle. One inclusion in diamond (Kankan, Guinea) has been reported where K-hollandite might have been the precursor (Stachel et al., 2000).

\section{$\mathrm{KMGF}_{3}$ PEROVSKITE}

$\mathrm{KMgF}_{3}$ (and F-bearing clinohumite and chondrodite) is stable up to at least $10 \mathrm{GPa}$ and $1400{ }^{\circ} \mathrm{C}$ as subsolidus breakdown products of phlogopite upon increasing $\mathrm{P}$ (Harlow, 2002), thus some phlogopite (or melts) may be a reaction product of these phases upon uplift.

\section{K-CYMRITE}

K-cymrite (or hydrous hexasanidine- $\mathrm{KAlSi}_{3} \mathrm{O}_{8} \cdot \mathrm{nH}_{2} \mathrm{O}$, $\mathrm{n} \leq 1$ ) is stable from $2.5 \mathrm{GPa}$ at $400{ }^{\circ} \mathrm{C}$ to $1000{ }^{\circ} \mathrm{C}$ and $\sim 6$ $\mathrm{GPa}$, depending upon water content, where it reacts to $\mathrm{Si}$ wadeite $\left(\mathrm{K}_{2} \mathrm{Si}_{4} \mathrm{O}_{9}\right)+$ kyanite + silica $+\mathrm{H}_{2} \mathrm{O}$ or melt; the reaction boundary has positive slope of $\sim 2.5 \mathrm{MPa} /{ }^{\circ} \mathrm{C}$ and is similarly placed to the anhydrous reaction sanidine $\Leftrightarrow$ K-wadeite + kyanite + silica. In experiments with a mixture of Di + sanidine + Phl, K-cymrite was found at 6$8 \mathrm{GPa}$ and $1200^{\circ} \mathrm{C}$ coexisting with $\mathrm{Cpx}+\mathrm{Phl} \pm$ kyanite \pm enstatite. K-cymrite formation appears to be highly dependent upon $\mathrm{H}_{2} \mathrm{O}$ content (activity) of the system; experiments indicate it is not stable at supersolidus conditions. Considering the strong effect $\mathrm{H}_{2} \mathrm{O}$ has on lowering melting temperatures, K-cymrite may be restricted to relatively high $\mathrm{P} / \mathrm{T}$ conditions and may react to sanidine upon equilibration or uplift. Study on Kcymrite continues.

\section{K-TI-SILICATE}

Perhaps related to $\mathrm{BaTi}_{9} \mathrm{O}_{20}$ (hollandite-like structure), a phase with apparent formula $\mathrm{K}[\mathrm{Si}, \mathrm{Ti}]_{9} \mathrm{O}_{20}$ was produced from sanidine-phlogopite lamproite in experiments at $>4.5 \mathrm{GPa}$ and $<1400-1500{ }^{\circ} \mathrm{C}$ (Mitchell, 1995). These $\mathrm{K}$-Ti silicates bear a passing resemblance to members of the crichtonite group, particularly mathiasite, $[\mathrm{K}, \mathrm{Ca}, \mathrm{Sr}][\mathrm{Ti}, \mathrm{Cr}, \mathrm{Fe}, \mathrm{Mg}]_{21} \mathrm{O}_{38}$, which are formed by kimberlite-related (?) metasomatism in the upper mantle (Haggerty et al., 1983).

\section{SI-WADEITE}

Si-wadeite (or K-wadeite $-\mathrm{K}_{2} \mathrm{Si}_{4} \mathrm{O}_{9}$ ) is a common product in K-rich experiments with stability from 6 to $>12 \mathrm{GPa}$, typically limited by reactions forming sanidine, Kcymrite, or K-hollandite. There are no citations of Kwadeite in natural samples, although the mineral wadeite, $\mathrm{K}_{2} \mathrm{ZrSi}_{3} \mathrm{O}_{9}$, found in alkaline rocks and carbonatites, may be stable at high pressure.

\section{(21)-MHP}

The mixed-chain (21)-hydrous clinopyribole, nominally $\mathrm{KNa}_{2} \mathrm{Ca}_{2} \mathrm{Mg}_{6} \mathrm{AlSi}_{12} \mathrm{O}_{34}(\mathrm{OH})_{2}$ - a combination of $\mathrm{K}$ richterite plus 2 omphacite formulae, was found in experiments on a KNCMASH bulk composition by Konzett and Fei (2000). Recent work with compositions approximating its own composition, (21)-MHP is stable from 5-18 GPa and $1100-1600{ }^{\circ} \mathrm{C}$ (Konzett and Japel, in press); moreover, potassium has been shown to be necessary to produce this clinopyribole.

\section{K-PHASE-1}

$(\mathrm{K}, \mathrm{Na})_{2} \mathrm{Mg}_{4} \mathrm{Si}_{4} \mathrm{O}_{13}$ and related $\mathrm{K}$-rich phases have been reported at high $\mathrm{P}$ in experiments (see Table 1) but the low-melting temperature (sub-geotherm) make them unlikely candidates as a sink or sampleable phase in the mantle.

\section{AL-RICH PHASE}

A phase with a composition like $[\mathrm{K}, \mathrm{Na}]_{0.9}[\mathrm{Mg}, \mathrm{Fe}]_{2}[\mathrm{Mg}, \mathrm{Fe}, \mathrm{Al}, \mathrm{Si}]_{6} \mathrm{O}_{12}$ with up to $\sim 7 \mathrm{wt} \%$ $\mathrm{K}_{2} \mathrm{O}$ has been reported in experiments (Gasparik and Litvin, 2002) at $24 \mathrm{GPa}$ from the breakdown of garnet to perovskite in the presence of potassium and invoked as a partial explanation for a cpx-corundum pair from a São Luiz, Brazil diamond (Hutchinson, 1997). 


\section{ACKNOWLEDGEMENTS:}

The authors apologize to researchers who have not been directly cited in this manuscript, but concerns for length led to this decision. In the final version we will address the missing citations. We gratefully acknowledge the National Science Foundation (EAR-9314819 \& EAR9903203) for support of this research.

\section{REFERENCES:}

Chamorro, E.M., Brooker, R.A., Wartho, J.-A., Wood, B.J., Kelly, S.P., and Blundy, J.D., 2002. Ar and K partitioning between clinopyroxene and silicate melt to 8 GPa. Geochimica et Cosmochimica Acta 66, 507-519.

Domanik, K.J., and Holloway, J.R., 1996. The stability of phengitic muscovite and associated phases from 5.5 to $11 \mathrm{GPa}$ : implications for deeply subducted sediments. Geochim. Cosmochim. Acta 60 (21), 4133-4150.

Domanik, K.J., and Holloway, J.R., 2000. Experimental synthesis and phase relations of phengitic muscovite from 6.5 to $11 \mathrm{GPa}$ in a calcareous metapelite from the Dabie Mountains, China. Lithos 52, 51-77.

Fasshauer, D.W., Chatterjee, N.D., and Marler, B., 1997. Synthesis, structure, thermodynamic properties and stability of K-cymrite, $\mathrm{K}\left[\mathrm{AlSi}_{3} \mathrm{O}_{8}\right] \times \mathrm{H}_{2} \mathrm{O}$. Physics and Chemistry of Minerals 24, 455-462.

Gasparik, T., and Litvin, Y.A., 2002. Experimental investigation of the effect of metasomatism by carbonatic melt on the composition and structure of the deep mantle. Lithos 60 , 129-143.

Gasparik, T., Tripathi, A., and Parise, J.B., 2000. Structure of a new Al-rich phase, $[\mathrm{K}, \mathrm{Na}]_{0.9}[\mathrm{Mg}, \mathrm{Fe}]_{2}[\mathrm{Mg}, \mathrm{Fe}, \mathrm{Al}, \mathrm{Si}]_{6} \mathrm{O}_{12}$, synthesized at $24 \mathrm{GPa}$. Amer. Mineral. 85, 613-618.

Haggerty, S.E., Smyth, J.R., Erlank, A.J., Rickard, R.S. and Danchin, R.V., 1983. Lindsleyite (Ba) and mathiasite (K): two new chromium-titanates in the crichtonite series from the upper mantle. Amer. Mineral. 68, 494505.

Harlow, G.E., 1997. K in clinopyroxene at high pressure and temperature: An experimental study. Amer. Mineral. 82, 259-269.

Harlow, G.E., 2002. Diopside + F-rich phlogopite at high P and $\mathrm{T}$ : Systematics and the stability of $\mathrm{KMgF}_{3}$, clinohumite and chondrodite. Geol. Mat. Res. v4n3, 1-28.

Harlow, G.E. and Veblen, D.R., 1991. Potassium in clinopyroxene inclusions from diamonds. Science, 251, 652-655.

Hutchison, M.T., 1997. The constitution of the deep transition zone and lower mantle shown by diamonds and their inclusions. Ph.D. Thesis, University of Edinburgh.

Konzett, J., and Fei, Y., 2000. Transport and storage of potassium in the Earth's upper mantle and transition zone: an experimental study to $23 \mathrm{GPa}$ in simplified and natural bulk compositions. J. Petrol. 41, 583-603.

Konzett, J., and Japel, S.L, in press. High P-T phase relations and stability of an ordered (21)-hydrous clinopyribole in the system $\mathrm{K}_{2} \mathrm{O}-\mathrm{Na}_{2} \mathrm{O}-\mathrm{CaO}-\mathrm{MgO}-\mathrm{Al}_{2} \mathrm{O}_{3}-\mathrm{SiO}_{2}-\mathrm{H}_{2} \mathrm{O}$ : an experimental study to $18 \mathrm{GPa}$. Amer. Mineral.

Konzett, J., Sweeney, R.J., Thompson, A.B., and Ulmer, P., 1997. Potassium amphibole stability in the upper mantle: an experimental study in a peralkaline KNCMASH system to $8.5 \mathrm{GPa}$. J. Petrol. 38, 537-568.

Konzett, J., and Ulmer, P., 1999. The stability of hydrous potassic phases in lherzolitic mantle - an experimental study to $9.5 \mathrm{GPa}$ in simplified and natural bulk compositions. J. Petrol. 40, 629-652.

Luth, R.W., 1997. Experimental study of the system phlogopitediopside from 3.5 to $17 \mathrm{GPa}$. Amer. Mineral. 82, 11981209.

Massone, H.-J., 1999. Experimental aspects of UHP metamorphism in pelitic systems. Int. Geo. Rev. 41, 623-638.

Matveev, Y.A., Litvin, Y.A., Perchuk, L.L., Chudinovskikh, L.T., and Yapaskurt, V.O., 1998. Intensive carbonatesilicate reactions $\mathrm{K}_{2} \mathrm{Mg}\left(\mathrm{CO}_{3}\right)_{2}-\left(\mathrm{Ca}_{0.5} \mathrm{Mg}_{0.5}\right) \mathrm{SiO}_{3}-\mathrm{Al}_{2} \mathrm{O}_{3}$ system in experiment at $7 \mathrm{GPa}$ : relation to Kokchetavtype diamond deposits. Terra Nova 10, (Supplement No. 1), 39 (Terra Abstracts)

Mellini, M., and Cundari, A., 1989. On the reported presence of potassium in clinopyroxene from potassium-rich lavas: a transmission electron microscope study. Min. Mag. $\underline{53}, 311-314$.

Mitchell, R.H., 1995. Melting experiments on a sanidine phlogopite lamproite at 4-7 $\mathrm{GPa}$ and their bearing on the sources of lamproite magmas. J. Petrol. 36, 1455-1474.

Perchuk, L.L., Safonov, O.G., Yapaskurt, V.O., and Barton J.M., 2002. Crystal-melt equilibria involving potassiumbearing clinopyroxene as indicator of mantle-derived ultrahigh-potassic liquids: an analytical review. In: Mineral equilibria in mantle-derived rocks (Perchuk, L.L, and Gasparik, T. ,eds.). Lithos 60, 3-4, 89-111.

Schmidt, M.W., 1996. Experimental constraints on recycling of potassium from subducted oceanic crust. Science 272, 1927-1930.

Stachel, T., Harris, J.W. Brey, G.P., and Joswig, W., 2000. Kankan diamonds (Guinea) II: lower mantle inclusion parageneses. Contrib. Min. Petrol. 140, 16-27.

Sudo, A. and Tatsumi, Y., 1990. Phlogopite and K-amphibole in the upper mantle: Implication for magma genesis in subduction zones. Geophys. Res. Lett. 17, 29-32.

Thompson, P., Parsons, I., Graham, C. and Jackson, B., 1998. The breakdown of potassium feldspar at high water pressures. Contrib. Min. Petrol. 130, 176-186.

Urakawa, S., Kondo, T., Igawa, N., Shimomura, O., and Ohno, N., 1994. Synchrotron radiation study on the highpressure and high-temperature phase relations of $\mathrm{KAlSi}_{3} \mathrm{O}_{8}$. Phys. Chem. Min. 21, 387-391.

Wang, W. and Takahashi, E., 1999. Subsolidus and melting experiments of a K-rich basaltic composition to $27 \mathrm{GPa}$ : Implication for the behavior of potassium in the mantle. Amer. Mineral. 84, 357-361.

Wang, W. and Takahashi, E., 2000. Subsolidus and melting experiments of a K-doped peridotite KLB-1 to 27 GPa: Its geophysical and geochemical implications. J. Geophys. Res. 105, 2855-2868. 
Yagi, A., Suzuki, T. and Akaogi, M., 1994. High pressure transition in the system $\mathrm{KAlSi}_{3} \mathrm{O}_{8}-\mathrm{NaAlSi}_{3} \mathrm{O}_{8}$. Phys. Chem. Min. 21, 12-17.

Contact: GE Harlow, Dept. Earth \& Planetary Sciences,

American Museum of Natural History, Central Park West at $79^{\text {th }}$

St., New York, NY 10024-5192 USA, E-mail:

gharlow@amnh.org 